\title{
Children's' Travel to School and Parents' Criteria in the School Selection: Gombak District
}

\author{
Nuraihan Mohd Ibrahim, Mariana Mohamed Osman, Syahriah Bachok
}

Kulliyah of Architecture and Environmental Design, International Islamic

University Malaysia, Kuala Lumpur, 50728, Malaysia

nuraihanibrahim@gmail.com

\begin{abstract}
School is a nucleus of the society. School development should be planned based on the sustainable concept. The purpose of this paper is to determining parents' criteria in selecting the suitable public school for their children. There are various factors underlying in determining the school selection which are location, distance, school facilities, academic school's performance, extra-curricular and school environment. The findings showed that academic school's performance is the most important criteria of parents in selecting school for enrolling children. Hopefully, the paper will benefit the local authority, parents as well as children in term of public school development in the community.
\end{abstract}

Keywords: school; school development; parents; criteria

eISSN 2398-4279 @ 2018. The Authors. Published for AMER ABRA cE-Bs by e-International Publishing House, Ltd., UK. This is an open access article under the CC BY-NC-ND license (http://creativecommons.org/licenses/by$n c-n d / 4.0 /$ ). Peer-review under responsibility of AMER (Association of Malaysian Environment-Behaviour Researchers), ABRA (Association of Behavioural Researchers on Asians) and CE-Bs (Centre for EnvironmentBehaviour Studies), Faculty of Architecture, Planning \& Surveying, Universiti Teknologi MARA, Malaysia.

DOI: https://doi.org/10.21834/ajqol.v3i9.76 


\subsection{Introduction $11 \mathrm{AN}$ bold}

Globally, human capital is developed by the school education to interact with the environment and knowledge (Cheng, 2013). This brief summarizes research on public school development and planning as well as determines parents' criteria in selecting public school. Over the past few years, traffic safety of the students when going to school has been a concern in the metropolitan area. Therefore, this paper also explores factors that influence transportation modes of the students during a trip to school. This study is a vital aspect for school planning, and as such the paper focuses for the future development of public schools.

\subsection{Research Problems}

School location affects how students going to school by given them various transportation modes (U.S. Environmental Protection Agency, 2003; The Oregon School Siting Handbook, 2005; McKoy et al, 2008). Ewing et al. (2004) and McDonald (2007) both mentioned that the primary obstacle for students to walk to school is because of the increased distances between school and home. In addition, Sri Maryati, et al (2002) stated travel distance to primary school normally within walking distance. According to Roya Shokoohi et al (2012), students are more likely to use automobiles as transportation modes during a trip to school. De Boer (2005) and Vigne (2007) stated that traffic congestion and accident are some of the significant problems associated with traffic safety in school involving children during a school trip.

\subsection{Research Background}

The research aims at determining parents' criteria in selecting the suitable public school for their children. The duration of study is twelve months. The scope of the study is only focusing on the transportation modes of the students during a school trip and factors influencing criteria in school selection. This study only covers on the selected primary and secondary public schools in Gombak District.

\subsection{Literature Review}

\subsection{Definition of Terms}

It is important to understand the meaning of school in order to derive the understanding of the function of school and its significance towards the society. However, in the context of this research paper, public schools that need to be taken into account are those schools under the management of the government. Table 1 below shows several components and their definition in relation with the topic. 
Table 1. Definition of Terms

\begin{tabular}{ll}
\hline Components & Definitions \\
\hline Parent & "Parent" includes a guardian and any person who has legal or actual control of a p \\
Pupil & "Pupil" means a person of any age for whom education or training is being provid \\
& an educational institution. \\
Teacher & "Teacher" means a person who - \\
& a) teaches pupils in an educational institution; or \\
& b) prepares or issues lessons or corrects returned answers in, for or throu \\
&
\end{tabular}

School

Government School

"School" means a place where ten or more persons gain knowledge whether in or more classes, but does not include any area where there is a restriction in teac exclusively to the teaching of any religion.

"Government school" or "government educational institution" means a school educational institution established and fully maintained by the Minister "governn aided school" or "government-aided educational institution" means a school 0 educational institution in receipt of capital grant and full grant-in-aid.

(Source: Malaysian Education Act, 1996)

\subsection{School choice}

School choice is parents' rights of selecting the most preferred school for their child to attend (Burgess, 2009). Students who are getting access to their favourable school will have better academic achievement than students who are not receiving access to school (Cullen et al, 2003; Cullen et al, 2005). The essential of school choice is from numerous policies which allowing students to be transferred out from the current school to a new school within the neighbourhood area (Rabovsky, 2011). However, there is also an argument where school choice would create racial segregations in terms of ability, income, ethnicity and religion (Cullen et al. 2005; Böhlmark and Lindahl, 2007; Rabovsky, 2011).

\subsection{Planning guidelines for school development}

In Malaysia, the development of school is using the planning standards and guidelines are as reference in planning a school. Based on the Table 2, it showed that the location of both primary and secondary schools are within the walking distance.

Table 2. Planning standards and guidelines for schools

\begin{tabular}{|c|c|c|}
\hline Types of school & Primary School & Secondary School \\
\hline Population & $3,000-7,000$ residents & $>9,000$ residents \\
\hline \multirow{4}{*}{ Allocation } & - $\quad 0.4-0.8 \mathrm{~km}$ & - $\quad 0.4-0.8 \mathrm{~km}$ \\
\hline & - $\quad 5-10$ minutes walking distance & - $\quad 5-10$ minutes walking distance \\
\hline & from the furthest house & from the furthest house \\
\hline & - $\quad$ Far from the intersection & Far from the intersection \\
\hline
\end{tabular}




\begin{tabular}{|c|c|c|c|c|}
\hline \multirow[b]{2}{*}{ Acreage (minimum) } & \multicolumn{2}{|c|}{$\begin{array}{l}\text { - } \text { Direct access to the road } 20.1 \mathrm{~m} \\
166^{\prime} \text { (within a residential area) } \\
\text { - Has public transportation } \\
\text { routes }\end{array}$} & \multicolumn{2}{|c|}{$\begin{array}{l}\text { - } \quad \text { Direct access to the road } 20.1 \mathrm{~m} \\
166^{\prime} \text { (within a residential area) } \\
\text { - } \quad \text { Has public transportation routes }\end{array}$} \\
\hline & $\begin{array}{l}\frac{\text { Flat Surface }}{2.4 \text { hectare }} \\
\text { (6 acre) }\end{array}$ & $\begin{array}{l}\frac{\text { Hilly area }}{3.2 \text { hectare }} \\
\text { (8 acre) }\end{array}$ & $\begin{array}{l}\frac{\text { Flat Surface }}{2.4 \text { hectare }} \\
(6 \text { acre })\end{array}$ & $\begin{array}{l}\frac{\text { Hilly area }}{3.2 \text { hectare }} \\
\text { (8 acre) }\end{array}$ \\
\hline \multicolumn{5}{|l|}{ Setback } \\
\hline Facing road & $12.2 \mathrm{~m}$ & & $12.2 n$ & \\
\hline Boundary & $6.1 \mathrm{~m}$ & & $6.1 \mathrm{~m}$ & \\
\hline $\begin{array}{ll}\text { Parking Area } \\
- & \text { Car } \\
- & \text { Motorcycle } \\
- & \text { Disabled }\end{array}$ & $\begin{array}{ll}- & 1 \text { car p } \\
\text { of car } \\
\text { - } & \text { Additio } \\
& \text { parking }\end{array}$ & $\begin{array}{l}\text { lot } / 2 \text { staffs }+20 \% \\
\text { lot for visitors } \\
\% \text { of motorcycle }\end{array}$ & $\begin{array}{l}1.5 \mathrm{ca} \\
\text { - } \quad \text { Additic } \\
\text { - } \quad \text { lot/30 } \\
\text { - } \quad \text { Additic } \\
\text { the prc }\end{array}$ & $\begin{array}{l}\text { lot/ } 2 \text { staffs }+20 \% \\
\text { or visitors } \\
\text { motorcycle parking } \\
\text { parking area with } \\
\text { f ramp for disabled }\end{array}$ \\
\hline Facilities Components & $\begin{array}{ll}\text { - } & \text { Fences } \\
\text { - } & \text { Signag } \\
\text { - } & \text { Toilet } \\
\text { - } & \text { Field/C } \\
\text { - } & \text { Cante } \\
\text { - } & \text { Hall } \\
\text { - } & \text { Flag po } \\
\text { - } & \text { Library } \\
\text { - } & \text { Musoll } \\
\text { - } & \text { Gazeb }\end{array}$ & school address & $\begin{array}{ll}\text { - } & \text { Bus st } \\
\text { - } & \text { Electri } \\
\text { - } & \text { Pedes } \\
\text { - } & 1 \text { mair } \\
\text { - } & \text { Post g } \\
\text { - } & \text { Lay-bj } \\
& \text { drop-o } \\
\text { - } & \text { and ca } \\
\text { Bicycl }\end{array}$ & $\begin{array}{l}\text { way with roof } \\
\text { width) used for } \\
\text { k-up for school bus } \\
\text { with roof }\end{array}$ \\
\hline
\end{tabular}

(Source: Town and Country Planning Department of Selangor, 2010)

\subsection{Factors influencing parents' criteria in choosing public school}

Parents' perception on school criteria is necessary because these criteria will help them to select the most suitable school for their children. School distance is one of the attributes in choosing school (Beavis, 2004; O'Mahony, 2008; Burgess et al, 2009). Kaiser et al (1995) and Ewing et al (2004) both mentioned that school location influenced by the built environment factors because location will determine the accessibility and transportation mode of students going to school.

As school is an essential institution, it needs a conducive physical and social environment in order to provide a positive impact on students' academic performance (Tremblay, 2001; Asikhia, 2010; Nurul Syakima, 2011). School's organizational health plays a significant part in academic achievement of students and their excellence (Mohsen Farmahini Farahani et al, 2014). In term of learning environment, majority of the students prefer a calm environment; adequate lighting; fresh temperature; sitting in soft chairs; and in casual setting (Lorenzo and Lorenzo, 2013). Although education focuses on academic, most students enjoy the participation in co-curricular activities (Lawhorn, 2008). Wilkinson et al (2004) and Zainurin 
and Mohd Sabri (2011) both agree that relevant criteria for parents in choosing a school for their children is because of the extra co-curricular activities offered by the school.

\subsection{Methodology}

The primary data collected through a questionnaire survey in order to obtain information regarding the research. The questionnaire survey consists of three main sections:

- $\quad$ Section 1: Respondents' profile

- $\quad$ Section 2: Transportation modes to school

- Section 3: Parents' perception in criteria of choosing school

There are a total of 400 questionnaire forms distributed to the selected primary and secondary schools within Gombak District. The sampling method implemented in this study is convenience sampling. The targeted group for this research was the parents of students from the selected primary and secondary schools in Gombak District. Table 3 shows the distribution of the questionnaire surveys among the selected schools.

Table 3. Questionnaire survey distributions

\begin{tabular}{lll}
\hline Schools & Frequency & Percentage (\%) \\
\hline Primary Schools & & \\
SK Gombak Utara & 65 & 16.25 \\
SK Gombak 1 & 38 & 9.5 \\
SK Gombak 2 & 16 & 4.0 \\
SK Gombak Setia & 75 & 18.75 \\
SK Taman Setia & 16 & 4.0 \\
SK Taman Seri Gombak & 20 & 5.0 \\
Secondary Schools & & \\
SMK Sg Pusu & 49 & 12.25 \\
SMK Gombak Setia & 91 & 22.75 \\
SMK Seri Gombak & 30 & 7.5 \\
Total & 400 & 100.0 \\
\hline
\end{tabular}

(Source: Questionnaire Survey, 2013)

\subsection{Findings and Analysis}

\subsection{Transportation modes of students to the school}

Table 4 shows the transportation modes of children to school. There are several modes of transport that been used by children to go to the school such as walking, cycling, school bus, private vehicles and public transport. The identification of reasons in using transportation mode is identified in this study. The usage of particular transportation modes vary due to many reasons. From the survey, the reasons for children used certain types of mode choices are for them to be physically active, for their safety, to save cost, the unavailability of other transportation option, closer distance to home, closer distance to their parents' workplace 
and lastly to save time. From the survey, the most transportation mode that been used was private vehicles with the percentage of $54.75 \%(219)$ from the total number of respondents. Table 4 summarizes the transportation modes and reasons of using the particular transportation modes.

Table 4. Cross-tabulation between transportation modes and reasons of using the particular transportation modes

\begin{tabular}{|c|c|c|c|c|c|}
\hline \multirow[t]{2}{*}{ Reasons } & \multicolumn{5}{|c|}{ Transportation Modes } \\
\hline & Walking & Cycling & $\begin{array}{c}\text { School } \\
\text { Bus }\end{array}$ & $\begin{array}{c}\text { Private } \\
\text { Vehicles }\end{array}$ & $\begin{array}{l}\text { Public } \\
\text { Transport }\end{array}$ \\
\hline Physically active & 7.25 & 1.25 & 0 & 0 & 0 \\
\hline $\begin{array}{l}\text { Safety of the } \\
\text { children }\end{array}$ & 0.25 & 0 & 6.5 & 40 & 0 \\
\hline Save cost & 3.5 & 0.75 & 1.75 & 0 & 0 \\
\hline $\begin{array}{l}\text { No other } \\
\text { transportation } \\
\text { system }\end{array}$ & 1.75 & 0 & 3.25 & 0.75 & 6.5 \\
\hline Close to home & 9.75 & 2.75 & 0 & 0.5 & 0 \\
\hline $\begin{array}{l}\text { Close to } \\
\text { workplace }\end{array}$ & 0 & 0 & 0 & 5.75 & 0 \\
\hline Save time & 0 & 0 & 0 & 7.75 & 0 \\
\hline Total & 22.5 & 4.75 & 11.5 & 54.75 & 6.5 \\
\hline
\end{tabular}

(Source: Questionnaire Survey, 2013)

A Chi-square test was made in order to test the relationship between transportation modes and school distance. Hypothesis \#1: "There is a relationship between transportation modes and distance". The results of this test are shown in Table 6 below.

Table 5. Summary on hypotheses tested

\begin{tabular}{llllll}
\hline Variables & \multicolumn{3}{c}{ Hypotheses Tested } & Significant \\
\cline { 2 - 4 } & $\begin{array}{l}\text { Chi- } \\
\text { Square }\end{array}$ & df & $\begin{array}{l}\text { Asymp. } \\
\text { (2-sided) }\end{array}$ & Sig. & \\
$\begin{array}{l}\text { Value } \\
\text { Transportation modes VS Distance }\end{array}$ & 57.534 & 4 & .000 & Significant \\
$\begin{array}{l}\text { between School and Home } \\
\begin{array}{l}\text { Transportation modes VS Distance } \\
\text { between School and Workplace }\end{array}\end{array}$ & 48.245 & 4 & .000 & Significant \\
\hline
\end{tabular}

(Source: Questionnaire Survey, 2013) 


\subsection{Parents' perception in criteria of selecting school}

R.I.I. analyses parents' perception in criteria of selecting a school for their children. R.I.I. method transforms the answer's choice of in Likert scale to assess the ranking of each factor by using the following equation:

$$
\mathrm{R} I \mathrm{I}=\frac{\sum w}{A N}
$$

$W$ is the weighting given to each factor by the respondents, ranging from 1 to $5, A$ is the highest weight (i.e. 6 in the study) and $\mathrm{N}$ is the total number of samples. The parents' perception towards the criteria in selecting school has been scaled by; $1=1$ st choice, $2=2$ nd choice, $3=3 \mathrm{rd}$ choice, $4=4$ th choice, $5=5$ th choice and $6=6$ th choice. The six-point scores ranging from 1 to 6 are transformed to the relative importance indices for each of the school criteria. In the questionnaire survey, respondents are required to rank the most important criteria in selecting school to enroll their children. Based on the literature review, there were six primary criteria in the school selection namely school academic performance, school location, school distance, school facilities, school environment and extra co-curricular activities. Parents' perception towards school criteria analyzed using Relative Importance Index (RII). The mean results derived were listed in the ranking order to determine the most important criteria in the school selection for students' enrolment.

Table 6. Parents' perception in criteria of selecting school $(n=400)$

\begin{tabular}{|c|c|c|c|c|c|c|c|}
\hline \multirow[t]{2}{*}{ Criteria } & \multicolumn{6}{|c|}{ Frequeney of Respondents } & \multirow[t]{2}{*}{ शाI } \\
\hline & $\begin{array}{c}\text { Choive } \\
1 \\
(6)\end{array}$ & $\begin{array}{c}\text { Choice } \\
2 \\
(5)\end{array}$ & $\begin{array}{c}\text { Choive } \\
3 \\
(4)\end{array}$ & $\begin{array}{c}\text { Choice } \\
4 \\
(3)\end{array}$ & $\begin{array}{c}\text { Choice } 5 \\
\text { (2) }\end{array}$ & $\begin{array}{l}\text { Choice b } \\
\text { (1) }\end{array}$ & \\
\hline Academic & 175 & 59 & 98 & 29 & 32 & 7 & 0.790 \\
\hline Performance & $(1050)$ & [295] & [392] & {$[87]$} & (64) & (7) & (1) \\
\hline Location & $\begin{array}{c}94 \\
{[554]}\end{array}$ & $\begin{array}{c}84 \\
{[420]}\end{array}$ & $\begin{array}{l}72 \\
{[28 B]}\end{array}$ & $\begin{array}{c}53 \\
{[159]}\end{array}$ & $\begin{array}{c}67 \\
l 134\end{array}$ & (30) & $\begin{array}{c}0.652 \\
(2)\end{array}$ \\
\hline Distance & $\begin{array}{c}93 \\
{[555]}\end{array}$ & $\begin{array}{c}112 \\
(570)\end{array}$ & $\begin{array}{l}41 \\
{[164]}\end{array}$ & $\begin{array}{l}32 \\
{[95]}\end{array}$ & $\begin{array}{l}49 \\
(96)\end{array}$ & (73) & $\begin{array}{c}0.650 \\
(3)\end{array}$ \\
\hline School Facilities & $\begin{array}{l}24 \\
{[144]}\end{array}$ & $\begin{array}{c}60 \\
{[300]}\end{array}$ & $\begin{array}{c}95 \\
(380)\end{array}$ & $\begin{array}{c}127 \\
{[3 B 1]}\end{array}$ & $\begin{array}{c}54 \\
(106)\end{array}$ & $\begin{array}{l}40 \\
(40)\end{array}$ & $\begin{array}{c}0.547 \\
(4)\end{array}$ \\
\hline School Environment & $\begin{array}{c}14 \\
{[84]}\end{array}$ & $\begin{array}{c}37 \\
{[185]}\end{array}$ & $\begin{array}{l}68 \\
{[272]}\end{array}$ & $\begin{array}{c}93 \\
(279)\end{array}$ & $\begin{array}{l}67 \\
(134)\end{array}$ & $\begin{array}{c}121 \\
(121)\end{array}$ & $\begin{array}{c}0.448 \\
(5)\end{array}$ \\
\hline $\begin{array}{l}\text { Co-curricular } \\
\text { activity }\end{array}$ & $\begin{array}{c}0 \\
0 \\
0]\end{array}$ & $\begin{array}{c}48 \\
{[240]}\end{array}$ & $\begin{array}{l}27 \\
{[105]}\end{array}$ & $\begin{array}{l}67 \\
{[201]}\end{array}$ & $\begin{array}{l}130^{\circ} \\
(260)\end{array}$ & $\begin{array}{l}128 \\
(128)\end{array}$ & $\begin{array}{c}0.390 \\
(6)\end{array}$ \\
\hline
\end{tabular}

(Source: Questionnaire Survey, 2013)

Based on the findings, academic performance is the most preferred criteria for parents in choosing a school for their children, with R.I.I scores of 0.79 highlighted in the Table 6 . There were $43.75 \%$ (175) of the respondents chose academic performance of the school as their first choice while there were only $1.75 \%$ (7) of the respondents chose school academic 
performance as the sixth choice for the most important criteria in school selection. This is followed by location with R.I.I scores of 0.652 , distance with R.I.I scores of 0.65 , school facilities with R.I.I scores of 0.547 and school environment with R.I.I scores of 0.448 . The cocurricular activity has the lowest R.I.I scores with 0.39 . Based on the survey, there were $32 \%$ (128) of the respondents chose extra co-curricular as their sixth choice whereby there was zero number of respondents chose extra co-curricular activities as their first choice in the school selection.

\subsection{Discussions and Conclusion}

The research was aimed at determining parents' criteria in selecting the suitable public school for their children. There are two main objectives for this research. Firstly, to identify the transportation modes of students when going to school and secondly to examine parents' criteria in selecting school for their children.

From the findings, the transportation modes that had been used by students going to school are walking, cycling, school bus, private vehicle and public transportation. Several reasons of using mode choices are health, safety, cost, distance and time. Most of the parents send their children to the school by using private vehicles. This is because they are concerning about the children's safety. Besides, the distance is closer to their workplace. Roya Shokoohi et al (2012) mentioned that neighbourhood safety becomes a concern of parents which leads them to use private vehicles to send their children to school. Some students are walking and cycling to school because the location of the school is closer to home. According to Ewing et al., 2004; the shorter distance between school and home encourages children to walk or cycle during a school trip. The relationship between distance and transportation modes was tested using chi-square test. The result shows that the critical value $(0.000)$ is less than 0.05 which concluded that there is a relationship between transportation modes and distance. Mode choice to school may differ from one place to another because it influenced by parents' perception towards factor such as distance and traffic safety (Carlin, 1997; Ewing et al., 2004; McMillan, 2005).

Based on the respondents, there are six primary criteria of parents in selecting school for the children which are academic performance, location, distance, school facilities, school environment and co-curricular activities. From the opinion of the parents, school performance ranked as the most influential criteria in choosing a suitable school for their children. This is followed by location (rank 2), distance (rank 3), school facilities (rank 4), school environment (rank 5) and lastly extra co-curricular activity (rank 6). Based on Schneider (2003), the improvement of educational achievement at national level influences the decision of school choice by the parents. As been mentioned by Burgess (2009), parental demand for academic performance is a crucial element in strengthening school choice that will enhance the school performance. Extra co-curricular activity is ranked as the least important criteria because students only participating in the co-curricular activity because it is compulsory for them.

As conclusion, a good school has always been an important factor for parents in deciding where to send their children. The study is significant for various parties such as local planning authority, parents and students. This study will contribute to the decision making by 
local authorities. The decision making includes the preparation in preparing the site of public school location. Parents will get benefits from this research in term of criteria that they need to know in selecting the suitable school for their children. As students, they will get the benefits by having a safe and healthy learning environment of the school. As location is necessary in planning a school, school must be located in the strategic area so that it will promote walking and cycling to school. Apart from the school physical planning, the school system also should be improved in term of the academic performance because it is a key factor for parents to choose the school for their children.

\section{References}

Alvaera A. B. et al., (2009), Teaching Approach, Perceived Parental Involvement and Autonomy as Predictors of Achievement, The International Journal of Research and Review, Vol. 1, pg. 57-80

Asikhia O. A., (2010), Students and Teachers' Perception of the Causes of Poor Academic Performance in Ogun State Secondary Schools (Nigeria): Implications for Couselling for National Development, European Journal of Social Sciences, Vol 13, No. 2, pg. 1-14

Beavis A., (2004), Why Parents Choose Public or Private Schools, Research Developments, Vol. 12

Berry M. A., (2002), Healthy School Environment and Enhanced Educational Performance: The Case of Charles Young Elementary School, Washington, Dc

Böhlmark A. and Lindahl M., (2007), The Impact of School Choice on Pupil Achievement, Segregation and Costs: Swedish Evidence, Discussion Paper Series

Burgess S. et. al., (2009), What Parents Want: School Preferences and School Choice, Centre for Market and Public Organisation

Carlin, J. B. et al., (1997), Walking to School and Traffic Exposure in Australian Children, Australian and New Zealand, Journal of Public Health

Cheng, A., (2013), Enhancing School Learning Capacity by Conducting Knowledge Management, Procedia - Social and Behavioral Sciences 93 (2013), pg. $281-285$

Cullen J. B. et al, (2003), The Effect of School Choice on Student Outcomes: Evidence from Randomized Lotteries, NBER Working Paper Series

Cullen J. B. et al, (2005), The Impact of School Choice on Student Outcomes: An Analysis of the Chicago Public Schools, Journal of Public Economics Vol. 89, pg. 729- 760

De Boer E., (2005), The Dynamics of School Location and School Transportation, TR News 237 March-April

Ewing R., (2004), School Location and Student Travel: Analysis of Factors Affecting Mode Choice, Transportation Research Record: Journal of the Transportation Research Board, No. 1895, pg. 55-63

Kaiser E. J. et al, (2006), Urban Land Use Planning, Fifth Edition, University of Illinois

Lawhorn B., (2008), Extracurricular Activities: The Afterschool Connection, Occupational Outlook Quarterly

Laws of Malaysia, (2006), Act 550 Education Act 1996 
Lorenzo, A. R. and Lorenzo, B. U., (2013), Learning Styles of Teacher Education Students: Basis in Improving the Teaching - Learning Process, Procedia - Social and Behavioral Sciences 103 (2013), pg. 595 - 605

Marjohan Jamalis and Mohd Sofian Omar Fauzee, (2007), Developing Human Value through Extra-Curricular Activities, The Journal of Human Resource and Adult Learning, Vol. 3, No. 1, pg. 53-60

McKoy D. et. al., (2008), Integrating Infrastructure Planning: The Role of Schools

Mohsen Farmahini Farahani et al, (2014), The Study of The Relationship of Organizational Health of the Schools and that of the Students' Academic Achievement [A Case Study of High Schools of Kohkilouie and Boierahmad Province, Iran 2011], Procedia - Social and Behavioral Sciences 109 (2014), pg. 628 - 633

Roya Shokoohi et al, (2012), Children Walking to and from School in Tehran: Associations with Neighbourhood Safety, Parental Concerns and Children's Perceptions, Procedia - Social and Behavioral Sciences Vol.38, pg. 315 $-323$

Schneider M., (2003), Linking School Facility Conditions to Teacher Satisfaction and Success, National Clearinghouse for Educational Facilities

Sri Maryati et al, (2012), Effect of School Clustering Policy on Travel Distance of Urban School Children, Journal Of Asian Behavioural Studies, Vol. 2, No. 7.

The Oregon School Siting Handbook, (2005), Planning for Schools \& Liveable Communities

Town and Country Planning of Selangor, (2010), Planning Standards and Guidelines for Public Facilities

Tremblay S. et al., (2001), Factors Affecting Grade 3 Student Performance in Ontario: A Multilevel Analysis, Education Quarterly Review, Vol. 7, No. 4, pg. 25-36

U.S. Environmental Protection Agency, (2003), Travel and Environmental Implications of School Siting

Vigne N. C. L., (2007), Traffic Congestion around Schools, U.S. Department of Justice

Wilkinson et al., (2004), The Accountability of Private Schools to Public Values, Discussion Paper Number 71, The Australia Institute

Zainurin Dahari and Mohd Sabri Ya, (2011), Factors that Influence Parents' Choice of Pre-Schools Education in Malaysia: An Exploratory Study, International Journal of Business and Social Science, Vol. 2, No. 15, pg. 115-128 